\title{
MEIS2 wt Allele
}

National Cancer Institute

\section{Source}

National Cancer Institute. MEIS2 wt Allele. NCI Thesaurus. Code C104688.

Human MEIS2 wild-type allele is located in the vicinity of $15 q 14$ and is approximately 212 $\mathrm{kb}$ in length. This allele, which encodes homeobox protein Meis2, plays a role in transcriptional regulation. 